Acta vet. scand. $1973,14,107-117$.

From the Department of Microbiology and Immunology, Veterinary College of Norway, Oslo.

\title{
THE EFFECTS OF PEPTIDE-PRECIPITATING LIGNOSULPHONIC ACIDS ON THE IN VITRO PROTEOLYTIC ACTIVITY OF SOME ANIMAL AND MICROBIAL PROTEINASES
}

By

Bjørn Næss, Kåre Fossum and Olav Sandvik

\begin{abstract}
NÆSS, BJØRN, KARE FOSSUM and OLAV SANDVIK: The effects of peptide-precipitating lignosulphonic acids on the in vitro proteolytic activity of some animal and microbial proteinases. Acta vet. scand. $1973,14,107-117$. - It has been shown that lignosulphonic acids have an inhibitory effect on various animal and microbial proteinases. The activity of $0.005 \mathrm{mg}$ swine trypsin, $0.007 \mathrm{mg}$ bovine $\alpha$-chymotrypsin and the proteinase activity in $0.004 \mathrm{ml}$ of jejunum content from pig is inhibited $70-75 \%$ by $0.25-0.30 \mathrm{ml}$ of a solution containing 250 diffusion units of peptide-precipitating lignosulphonic acids per $50 \mu l$.

The inhibitory effect is discussed in relation to the use of animal foodstuffs containing lignosulphonic acids, and in relation to biochemical reactions taking place in ecosystems in which lignosulphonic acids comprise an important part.
\end{abstract}

lignosulphonic acids; proteinase inhibition; animal proteinases; microbial proteinases.

It has been shown that peptide-precipitating lignosulphonic acids have an inhibitory effect on the activity of pepsin when using the Anson procedure for the determination of proteolytic activity (Næss et al. 1973). This result is of interest because lignosulphonic acids have been under consideration for the treatment of peptic stomach ulcers, and because they also comprise part of certain animal foodstuffs (Næss et al.). The aim of the present work was to study the effects of various lignosulphonic aoids on the proteolytic activity of some other animal and, in addition, of some microbial proteinases. 


\section{MATERIALS AND METHODS}

Lignosulphonic acids. Lignosulphonic acids were prepared by dialysis of a fermented sulphite spent liquor, kindly supplied by Tofte Cellulosefabrik A/S, Hurum, Norway. The liquor used in the present work was tested by the CP-method of Sandvik (1962) and found not to contain detectable amounts of proteolytic enzymes. Dialysis was carried out against running tap water at room temperature for $18 \mathrm{hrs}$. These lignosulphonic acids are referred to as DSSL (dialyzed sulphite spent liquor). A stock solution ( $\mathrm{pH} 6$ ) was prepared containing $\overline{250}$ diffusion units of peptide-precipitating lignosulphonic acids per $50 \mu \mathrm{l}$ liquor (Næss 1971a). The lignosulphonic acids have been characterized by gel chromatography and determination of the peptide-precipitating ability of the fractions (Hildrum \& Næss 1972).

The sodium salt of lignosulphonic acids (LSA), prepared by the procedure of Jantzen (1967) was kindly supplied by Alwatech A/S, Oslo, Norway. These lignosulphonic acids have also been characterized by gel chromatography and determination of the peptide-precipitating ability of the fractions (Næss et al. 1973).

The $\mathrm{pH}$ of the LSA solutions used was adjusted to $\mathrm{pH} 6$. Various gel chromatography fractions of LSA were prepared as described previously (Nass et al.). These fractions are hereafter called LSA samples $1,2,3$ and 4 and contain $4 \%$ of lignosulphonic acids. LSA sample 1 contains mainly high-molecular weight lignosulphonic acids, LSA samples 2 and 3 lignosulphonic acids of middle molecular weight, and LSA sample 4, low-molecular weight lignosulphonic acids (Hildrum \& Næss).

Enzymes. The bacterial proteinases were produced according to a procedure described by Sandvik, while endocellular yeast proteinases were prepared as described by Fossum (1970b). The following strains were used : Bacillus cereus ( $\mathrm{NVH}^{\star} 322$ ), Pseudomonas aeruginosa ( $\mathrm{NVH} \mathrm{982),} \mathrm{Clostridium} \mathrm{perfringens} \mathrm{(} N V H$ 839), Bacillus thuringiensis (ATCC * 10792), Vibrio cholerae (ATCC 14035), Proteus vulgaris (NVH 418), Corynebacterium pyogenes (NVH 431), Pseudomonas fluorescens (NVH 656), Serratia marcescens (NVH 2672), Saccharomyces cerevisiae var.

* The Culture Collection at the Department of Microbiology and Immunology, Veterinary College of Norway, Oslo, Norway.

* American Type Culture Collection, Rockville, Maryland, USA. 
ellipsoideus (ATCC 7753). Aspergillus oryzae protease (Type II, crude, lot 1320 ) and $\alpha$-chymotrypsin from bovine pancreas (Type II, $3 \times$ crystallized, lot 86B-0470) were obtained from Sigma* Trypsin ex hog pancreas (crystallized, batch No. 36367) and pronase ex Streptomyces griseus (Batch No. 45821) were obtained from Koch-Light ${ }^{\star \star}$.

The jejunum content of a pig (randomly selected at a slaughter-house) was collected after necropsy, and after centrifugation the supernatant was used as an enzyme source without further purification.

The content of proteinases in mud extracts from sulphite spent liquor recipients is considerable (Næss 1971b). Proteinase solutions from mud were prepared by collection of mud samples from two river recipients (Andelva, near Eidsvoll, and Drammenselva, Drammen, Norway) with a perforated metalbox fixed to the end of a rod. Samples of $20 \mathrm{ml}$ of mud were added $1 \mathrm{M}$ $\mathrm{NaOH}$ to $\mathrm{pH} 10$ and centrifuged after shaking thoroughly. The $\mathrm{pH}$ of the supernatant was adjusted to $\mathrm{pH}$ 7. The content of proteinases in the mud was calculated by the method of Sandvik to be $10000-20000$ diffusion units per ml packed centrifuged mud. The proteinases in the mud are assumed to be of microbial origin. Among the proteinase-producing bacteria in the mud, Bacillus cereus and Pseudomonas aeruginosa were identified in the samples.

Dry weight of enzymes is given only for the commercially obtained proteinases.

Determination of proteinase activity. For the qualitative detection of the proteinase inhibitory effect, the casein precipitating method (CP-method) of Sandvik, adapted for the determination of proteinase inhibitors as in the crosswise casein precipitating inhibition test (crosswise CPI-test) (Fossum 1970b), was used. Filter paper strips (Schleicher \& Schüll No. 2043 bmgl) moistened with the inhibitor-containing material were placed on an agar layer ( $2 \mathrm{~mm}$ thick) containing $1 \%$ sodium caseinate (pH 6.5) in $1.4 \%$ agar (Bacto-Agar, 0140-01, Difco***) with $0.01 \%$ merthiolate and $0.003 \mathrm{M}-\mathrm{MgCl}_{2}$, and incubated for about $3 \mathrm{hrs}$, at $37^{\circ} \mathrm{C}$. After removal of these strips, similar strips

* Sigma Chemical Company, St. Louis, Missouri, USA.

* Koch-Light Laboratories Ltd., Colnbrook, Bucks., England.

** Difco Laboratories Inc., Detroit, Michigan, USA. 


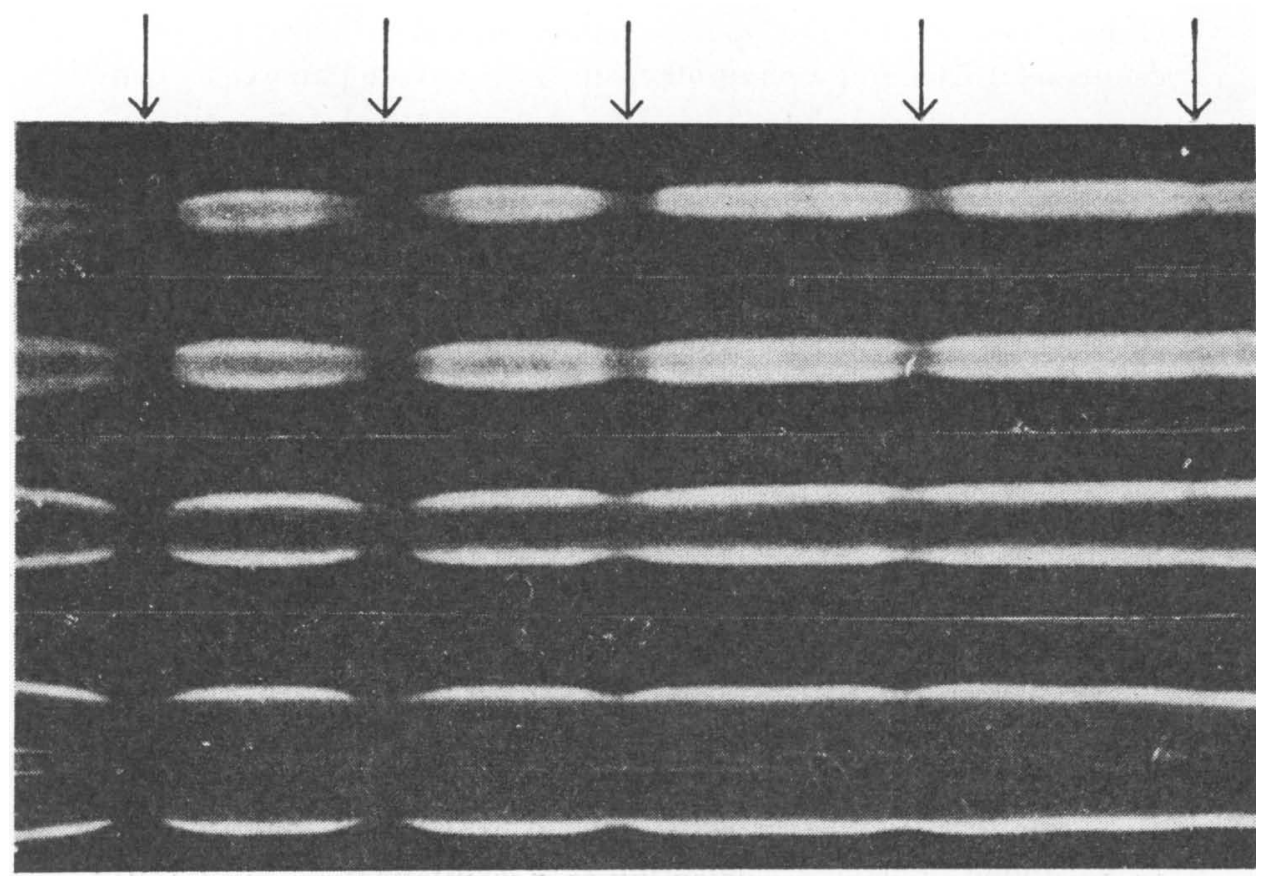

Figure 1. Crosswise CPI-test with different concentrations of jejunum content from pig and various concentrations of lignosulphonic acids in dialysed sulphite spent liquor (DSSL). The dilutions of DSSL are (from left to right as marked by arrows) : $\frac{1}{1}, \frac{1}{2}, \frac{1}{4}, \frac{1}{8}$ and $\frac{1}{1} \overline{6}$. The dilutions of jejunum content are (downwards) $: \frac{1}{10 \delta}, \frac{1}{\delta} \frac{1}{\delta}$, $\frac{1}{10}$, and $\frac{1}{1}$.

moistened with solutions of the proteolytic enzymes to be used were applied to the surface of the agar at right angles to the direction of application of the inhibitors, and the plates incubated for a further $12-18 \mathrm{hrs}$. at $37^{\circ} \mathrm{C}$. Proteolytic activity is indicated by white zones in the otherwise clear agar, and the inhibition is indicated by interruption of these white precipitation zones (Fig. 1). The casein digestion method of Kunitz (1947), as modified by Fossum (1970a), was also used. The digestion of $1 \mathrm{ml} 2 \%$ casein solution (Hammarsten quality, Merck ${ }^{*}$ ) by $0.005-0.007 \mathrm{mg}$ of crystalline enzyme or $0.004 \mathrm{ml}$ of jejunum content, and with $0.3 \mathrm{ml} 0.5 \mathrm{M}$ Tris-HCl buffer, $\mathrm{pH}$ 7.0, and various amounts of DSSL, was carried out by incubating the mixtures for $20 \mathrm{~min}$. at $37^{\circ} \mathrm{C}$, after which $3 \mathrm{ml} 5 \%$ trichloro-

- Merck, Darmstadt, Germany. 


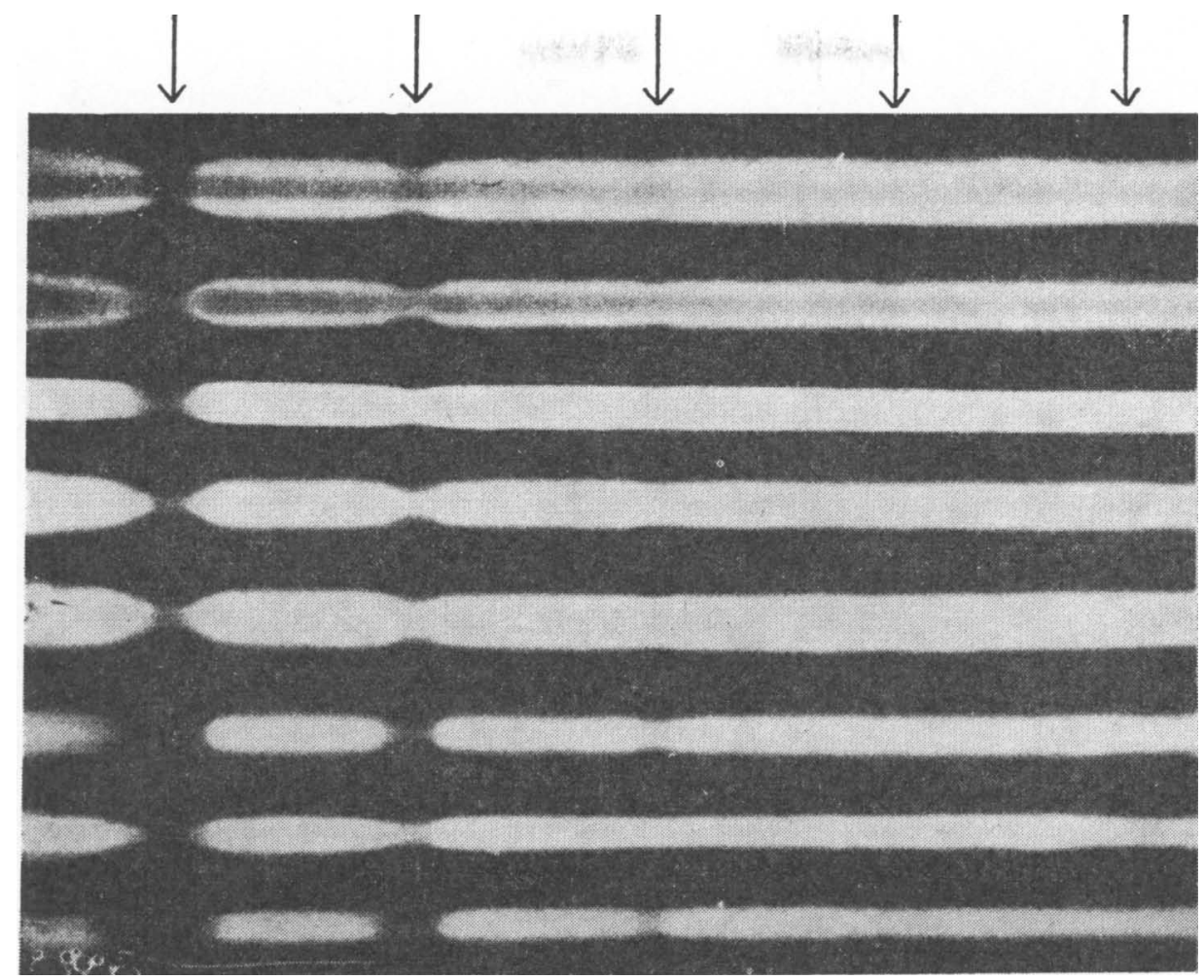

F i g u re 2. Crosswise CPI-test with different enzymes and various concentrations of the sodium salt of lignosulphonic acids (LSA). LSA concentrations are (from left to right as marked by arrows): $5 \%$ $\left(\frac{\mathrm{w}}{\mathrm{v}}\right), 2.5 \%, 1.2 \%, 0.6 \%$ and $0.3 \%$. The enzyme solutions used are (downwards): Swine trypsin $(0.01 \mathrm{mg}$ per $\mathrm{ml})$, bovine $\alpha$-chymotrypsin $(0.005 \mathrm{mg}$ per $\mathrm{ml})$, proteinases from Clostridium perfringens, Bacillus cereus, Pseudomonas aeruginosa, Aspergillus oryzae $(0.03 \mathrm{mg}$ per $\mathrm{ml}$ ), Saccharomyces cerevisiae and mud extract.

acetic acid was added to stop enzymatic activity and to precipitate the undigested proteins. The amounts of certain amino acids released during the protein digestion were estimated by adding $5 \mathrm{ml}$ of $0.5 \mathrm{M}-\mathrm{NaOH}$ and $1.5 \mathrm{ml}$ Folin-Ciocalteus Phenolreagent (Merck) to $2.5 \mathrm{ml}$ of the supernatant, and measuring the absorbances at $480 \mathrm{~nm}$ (Nxss et al.) in a Spectronic 20 photometer $^{*}$. The absorbance at $280 \mathrm{~nm}$ without added phenolreagent was not

* Bausch \& Lomb Inc., Rochester, USA. 


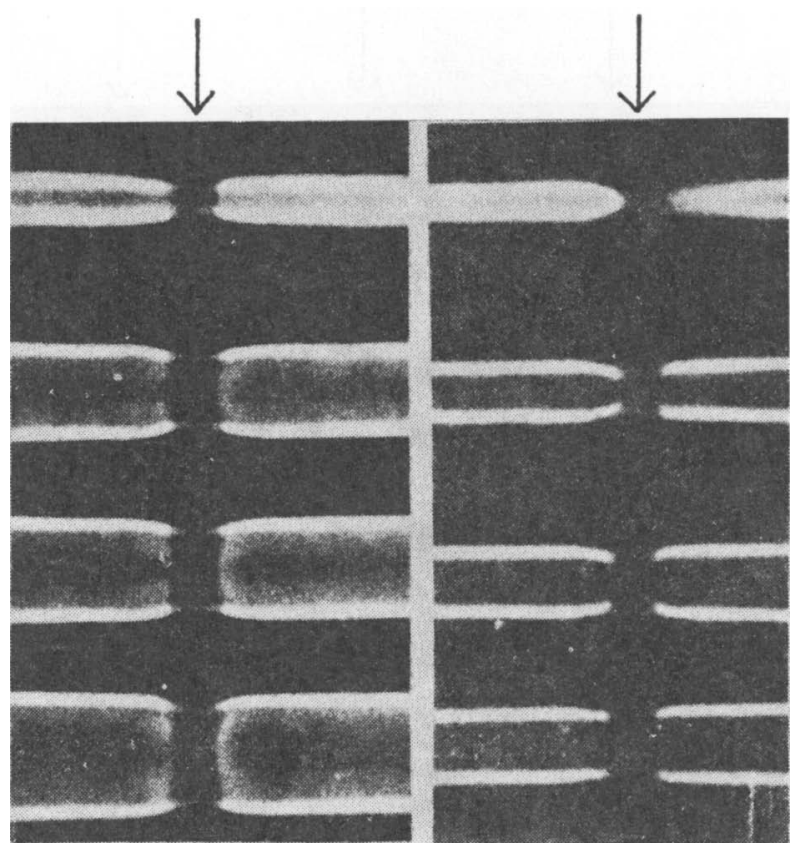

F ig u r e 3. Crosswise CPI-test of different concentrations of bovine $\alpha$-chymotrypsin (left) and swine trypsin (right) with undiluted DSSL. The enzyme solutions used are (downwards) : $\alpha$-chymotrypsin, $0.005 \mathrm{mg}$ per $\mathrm{ml}, 0.05 \mathrm{mg}$ per $\mathrm{ml}, 0.25 \mathrm{mg}$ per $\mathrm{ml}$ and $0.5 \mathrm{mg}$ per $\mathrm{ml}$. Trypsin, $0.01 \mathrm{mg}$ per $\mathrm{ml}, 0.1 \mathrm{mg}$ per $\mathrm{ml}, 0.5 \mathrm{mg}$ per $\mathrm{ml}$ and $1.0 \mathrm{mg}$ per ml.

used because of the great absorbance of lignosulphonic acids in this region (Hildrum \& Næss).

\section{RESULTS}

Fig. 1 shows the inhibitory effect of DSSL upon proteinases present in the jejunum content of a pig. It can be seen that the inhibitory effect can be demonstrated for the dilutions of DSSL used including $\frac{1}{16}$. This inhibitory effect also occurred for all the dilutions of jejunum content tested. When LSA were used an inhibitory effect could be detected with concentrations of LSA as low as $1.2 \%$.

The inhibitory effect of LSA upon eight different proteolytic enzymes is shown in Fig. 2. All the enzymes were inhibited to some extent by a $5 \%$ solution, but no inhibition could be seen 


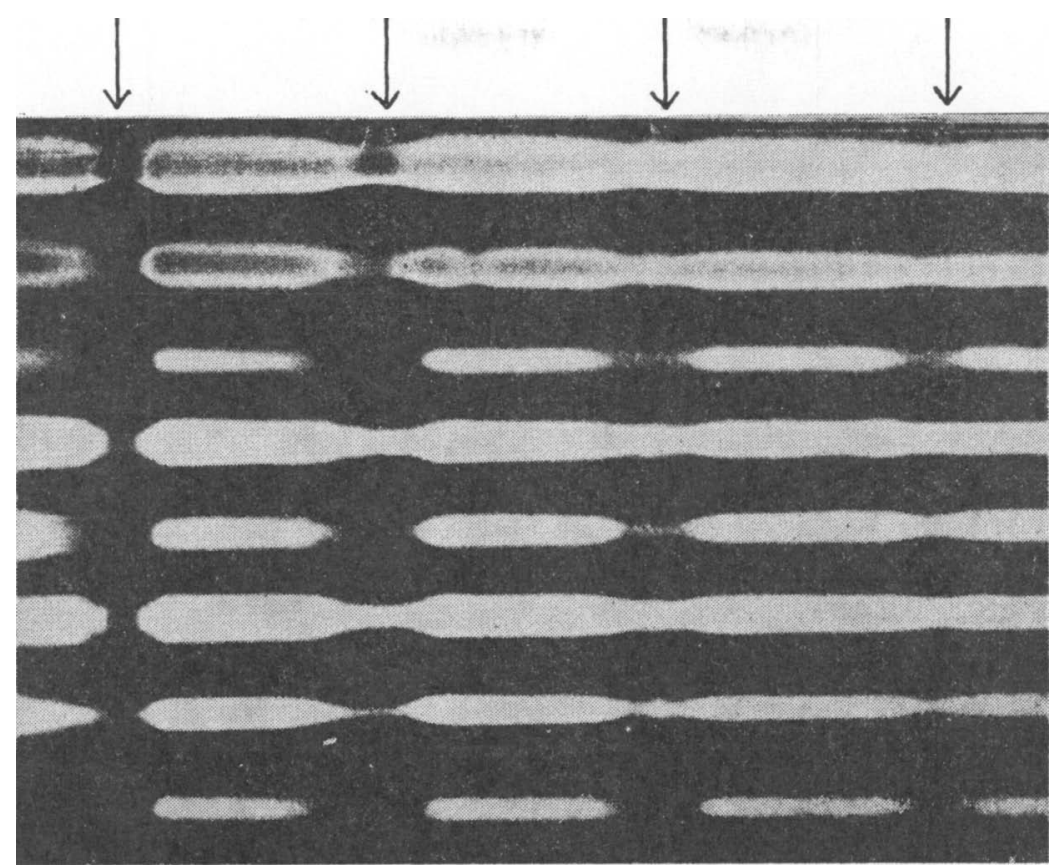

F i g u r e 4. Crosswise CPI-test with different enzymes and various gel chromatography fractions of LSA. The LSA fractions (4\% solutions) used are (from left to right as marked by arrows): LSA sample 1, 2, 3 and 4. The enzymes used are the same as listed downwards for Fig. 2.

for any of the enzymes when the solution contained less than $1.2 \%$ LSA. The other proteinases listed under materials and methods were inhibited similarly to those shown in Fig. 2. An inhibitory effect of DSSL could be demonstrated using great variations in the concentrations of the enzymes, as shown for $\alpha$-chymotrypsin and trypsin (Fig. 3). In Fig. 4 the inhibiting effect of various gel chromatography fractions of LSA upon the activity of eight different proteinases is shown. The activity of all the enzymes was inhibited by the four samples of LSA, but the degree of inhibition decreased with decreasing molecular weight of the lignosulphonic acids.

When using the Kunitz method for the demonstration of enzyme activity in the presence of lignosulphonic acids, it can be seen that the activity of $0.005 \mathrm{mg}$ trypsin, $0.007 \mathrm{mg} \alpha$-chymotrypsin and the proteinase activity in $0.004 \mathrm{ml}$ of jejunum con- 


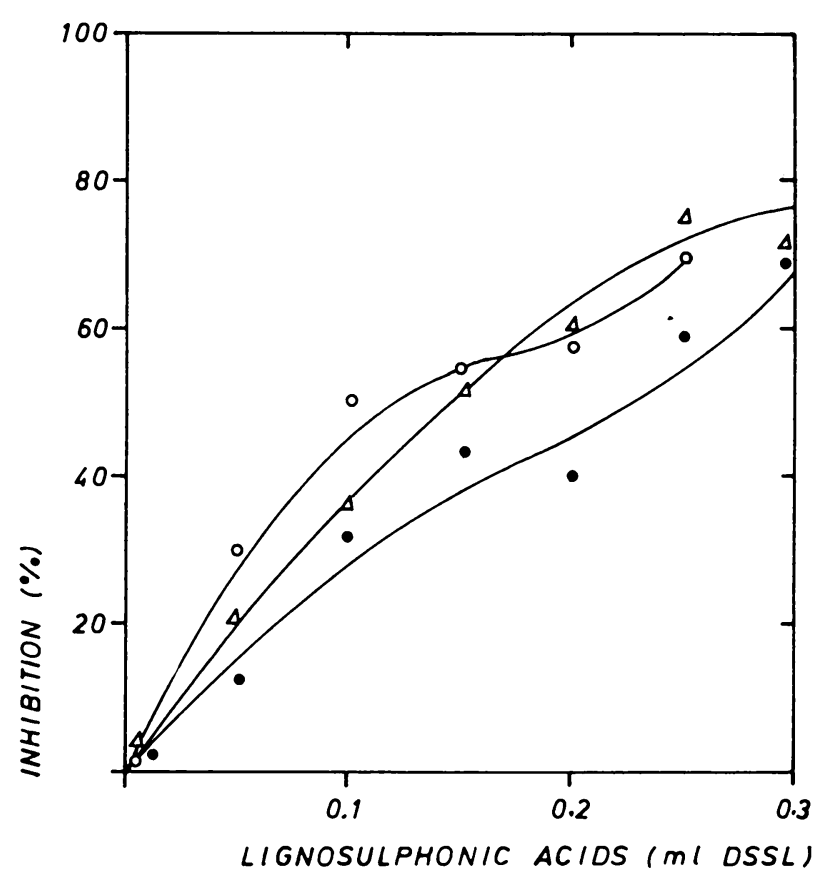

Figure 5. Per cent inhibition of swine trypsin o-o, bovine $\alpha$-chymotrypsin $\triangle-\triangle$ and jejunum content from pig $\bullet-\bullet$ by different amounts of DSSL as determined by the Kunitz method. The amounts of enzymes used are $0.005 \mathrm{mg}$ of swine trypsin, $0.007 \mathrm{mg}$ of $\alpha$-chymotrypsin and $0.004 \mathrm{ml}$ of jejunum content.

tent can be $70-75 \%$ inhibited by $0.25-0.30 \mathrm{ml}$ of DSSL (Fig. 5). As lignosulphonic acids also give a blue colour with the phenolreagent, it was not possible, with the photometer used, to measure the absorbances when more than $0.25-0.30 \mathrm{ml}$ of DSSL was used with the amounts of enzymes mentioned above.

\section{DISCUSSION}

The observation that lignosulphonic acids have an inhibitory effect on animal proteinases is of particular interest because lignosulphonic acids comprise parts of certain animal foodstuffs Næss et al. 1973). On the other hand, it has previously been demonstrated that peptide- and protein-lignosulphonic acid complexes can serve as substrates for certain proteolytic enzymes (Næss $1971 \mathrm{c}$ ). Relatively high concentrations of proteinases were, 
however, used when neopeptone-lignosulphonic acid complexes were incorporated as the substrate in an agar gel. The relative concentrations of the proteinases and the lignosulphonic acids seem to be of particular importance for the activity of proteinases in the presence of such acids. As the proteolytic activity of both pepsin (Næss et al.), and as shown in the present work, of trypsin, $\alpha$-chymotrypsin and extracellular Clostridium perfringens proteinase is reduced in the presence of adequate amounts of lignosulphonic acids, it is possible that the digestion by animals of protein foodstuffs in the presence of lignosulphonic acids is hindered. Another possibility is that the normal production of proteinases is sufficient for adequate digestion in the presence of proteinase inhibiting substances in the concentrations of interest, or also that a decreased protein digestion would stimulate the production of enzymes as compensation. Melmed \& Bouchier (1969) have shown that the oral ingestion of naturally occurring purified trypsin inhibitors from soy bean, ovomucoid, and bovine pancreas is potent stimuli to pancreatic digestive enzyme synthesis which may lead to impairment of growth in rat and chicken through the fecal loss of essential amino acids. This is thought to be due to the markedly potentiated secretion of pancreatic digestive enzyme protein overwhelming the normal digestive capacity of the gastrointestinal tract and resulting in a pancreatogenous protein-losing enteropathy. It would, therefore, be of great interest to study the effects of adding lignosulphonic acids in various concentrations to the diet of animals during a longer period. Of particular importance would be a study of the growth rate, analyses of total nitrogen in the feces and in the fodder compared to that of the controls, and to search for signs of hyperactivity of the enzyme-producing cells in the pancreas.

The observation that all the proteinases tested are inhibited by lignosulphonic acids, supports the theory previously discussed (Næss et al.) that the affinity of the lignosulphonic acids for substrate or enzyme, or both, is unspecific. However, no precipitation of substrate by lignosulphonic acids in the CP-agar was observed at the $\mathrm{pH}$ value used ( $\mathrm{pH}$ 6.5). This result differs from that seen in the study of pepsin with hemoglobin as substrate, as the hemoglobin was obviously precipitated by the lignosulphonic acids ( $\mathrm{pH}$ 2.1). On the other hand, soluble lignosulphonic acid complexes with substrate, or enzyme or both, may occur 
in the present system, and be responsible for the enzyme-inhibiting effect, or some part of it.

The observation that the high-molecular weight lignosulphonic acids have the greatest inhibitory effect upon the enzymes used is in accordance with the findings for pepsin.

In a previous study (Nxss $1971 \mathrm{~d}$ ), it was found that proteinase-digested peptide-lignosulphonic acid precipitates could be reprecipitated with peptides and proteins when the enzymes were inhibited. These reactions are considered as a cycle. Microbial proteinases are considered to be important in the degradation of peptide- and protein-lignosulphonic acid complexes. Such complexes, under certain conditions, probably comprise parts of the bottom mud and suspended material in sulphite spent liquor recipients, especially where waste liquors from dairies, slaughterhouses and other food industries are also discharged. The significance of the inhibitory effect of the lignosulphonic acids upon the mud proteinases, as demonstrated in the present work, is not known, but it is probable that they are of importance in relation to the biochemical activity of the ecosystems in which lignosulphonic acids comprise an important part. Blocking substances such as amino acids, certain amines and peptides (Nærs 1971d) may, however, also be of importance for the degree of enzyme inhibition caused by lignosulphonic acids in this connection.

\section{REFEFENCES}

Fossum, K.: Proteolytic enzymes and biological inhibitors I. Comparison between the Kunitz method and the agar gel casein precipitating reaction for determination of the activity of some commercial proteolytic enzymes and inhibitors. Acta path. microbiol. scand. 78B, $1970 \mathrm{a}, 350-362$.

Fossum, $K$.: Proteolytic enzymes and biological inhibitors IV. Bacterial proteinase inhibitors and their effect upon enzymes of various origin. Acta path. microbiol. scand. 78B, 1970b, 755-759.

Hildrum, K. I. \& B. Næss: Gel filtration of lignosulphonic acids and peptide-precipitating abilities of the separated fractions. Acta vet. scand. $1972,13,293-304$.

Jantzen, L.: Lignoprotein, animal feed. Aktieselskapet Christiania Portland Cementfabrik. Brit. 1.092.628 (Cl.C.07g), Nov. 29, 1967, Appl. Nov. 26, 1964.

Kunitz, M.: Crystalline soybean trypsin inhibitor II. General properties. J. gen. Physiol. 30, 1947, 291-310. 
Melmed, R. N. \& I. A. D. Bouchier: A further physiological role of naturally occurring trypsin inhibitors: The evidence for a trophic stimulant of the pancreatic ancinar cell. Gut 1969, 10, 973-979.

Næss, B.: Peptide-lignosulphonic acid precipitation zones in agar gel. A direct micro quantitative procedure for the determination of peptide-precipitating lignosulphonic acids in aqueous solution. Acta vet. scand. 1971a, 12, 583-591.

Næss, B.: Mikrobielle omsetninger i avfallsvann fra treforedlingsprosesser i ressursmessig og $\varnothing$ kologisk sammenheng. (Microbial activity in waste waters from chemical wood pulp processes, in relation to ecology and natural resources). Norsk vet.-T. $1971 \mathrm{~b}, 10,501-506$.

Næss, B.: The effect of microbial and animal proteinases on peptideand protein-lignosulphonic acid complexes in agar gel. Acta vet. scand. $1971 \mathrm{c}, 12,592-600$.

Næss, B.: The effect of proteinase-digested peptide-lignosulphonic acid complexes, dipeptides and amino acids on the formation of peptide-lignosulphonic acid precipitates. Acta agric. scand. 21, $1971 \mathrm{~d}, 199-207$.

Næss, B., O. Westbye, K. I. Hildrum \& I. Nafstad: The effects of peptide-precipitating lignosulphonic acids on the proteolytic activity of pepsin in vitro and on the response of pigs to an ulcer inducing diet. Acta vet. scand. 1973, 14, 44-56.

Sandvik, $O .:$ Studies on casein precipitating enzymes of aerobic and facultatively anaerobic bacteria. Thesis. Veterinary College of Norway, Oslo 1962.

\section{SAMMENDRAG}

Virkningen av peptidpresipilerende ligninsulfonsyrer in vitro pd den proteolytiske aktivitet av noen animalske og mikrobielle proteinaser.

Det er vist at ligninsulfonsyrer har hemmende virkning på forskjellige animalske og mikrobielle proteinaser. Aktiviteten av $0,005 \mathrm{mg}$ svinetrypsin, $0,007 \mathrm{mg} x$-chymotrypsin fra storfe og proteinaseaktiviteten i $0,004 \mathrm{ml}$ jejunuminnhold fra gris kan inhiberes 70-75\% med $0,25-0,30 \mathrm{ml}$ av en løsning som inneholder 250 diffusjonsenheter peptidpresipiterende ligninsulfonsyrer per $50 \mu l$.

En har diskutert den hemmende virkningen i forhold til bruken av visse fórstoffer som inneholder ligninsulfonsyrer og $\mathrm{i}$ forhold til biokjemiske reaksjoner som finner sted $\mathrm{i}$ økosystemer hvor ligninsulfonsyrer utgjør en viktig del.

(Received April 13, 1972).

Reprints may be requested from: Bjørn Næss, Department of Microbiology and Immunology, Veterinary College of Norway, Postbox 8146, Oslo Dep., Oslo 1, Norway. 